\title{
THE LONGEVITY OF THE SUPERMARKET AS A NON-PLACE IN DON DELILLO'S WHITE NOISE
}

\author{
UDC 821.111(73).09-31 De Lillo D.
}

\author{
Stefan Pajović \\ University of Novi Sad, Faculty of Philosophy, Novi Sad, Serbia
}

\begin{abstract}
The paper examines the setting of the supermarket as a non-place in Don DeLillo's novel White Noise, published in 1985, and its lastingness in contemporary culture. Critics have been mainly focusing on the consumerist and religious meaning of the place of the supermarket in the novel, disregarding its spatial implications. As a place, the concept of the supermarket is present in the philosophical thought of the French anthropologist Marc Augé who had developed the term "non-place" during the last decade of the twentieth century. It is this paper's aim to prove beyond doubt that DeLillo's concept of the supermarket, as portrayed in White Noise, matches Augé's notion of a non-place. Other non-places include: a hotel room, a highway, or an airport. Furthermore, there exists a difference between "space" and "place" which is essential for the genesis of a non-place, including the one of the supermarket. This shopping area is marked by transience and created with a certain intention in mind, but it simultaneously represents a familiar place, which is precisely the way numerous DeLillo's characters perceive it in the novel. The longevity of the supermarket as a non-place can be found in the present cultural context as well. The present-day symbolism of supermarkets is precisely the kind DeLillo wrote about and Augé expounded on.
\end{abstract}

Key words: supermarket, White Noise, non-place, Don DeLillo, space

\section{INTRODUCTION: ON NON-PLACES}

When the author of this text used a self-service checkout cash register in a shopping mall in Novi Sad not so long ago, he made a mistake of saying "goodbye" to the worker in charge of maintenance of the machines. Her job was not to interact with the customers, but to merely come to aid if a problem with the cash registers occurred. Needless to say, she was instantly dumbstruck and it took her a few seconds to realize she had been

Submitted May $9^{\text {th }} 2017$, accepted for publication December $5^{\text {th }}, 2017$

Corresponding author: Stefan Pajović

Faculty of Philosophy, Dr. Zoran Đinđića 2, 21000 Novi Sad, Serbia

E-mail: stefan@capsred.com

${ }^{1}$ The paper was presented at the Third International Conference on English Studies: English Language and Anglophone Literatures Today (ELALT 3), at the Faculty of Philosophy in Novi Sad in March 2015. The paper was supervised by Prof. Ivana Đurić Paunović, Phd. 
spoken to. The whole reason behind the existence of these automated checkout terminals is to avoid the interaction with the cashier, who is a human being. By using words, and kind ones to further add to the transgression, our shopper from the introductory sentence of the text, had violated a space which was not intended for human interaction. Such a space could hardly be deemed as a "place," and could be a form of a "non-place."

Firstly, we must define what a place actually is, if we wish to examine the absence of it. Not every location on planet Earth can be regarded as a place, ${ }^{2}$ since they acquire meaning in relation to their frequenters, namely, humans. Different locations have different meanings to us, and we agree with Creswell when he defines a place as "a meaningful location" (2004: 7). However, not every location that humans occupy can be regarded as a place.

Near the end of the twentieth century, the French anthropologist Mark Augé had defined the term "non-place" in relation to a type of social space that came into existence with the onset of hypermodernity. It is a place that exists in the real world but is dormant in terms of social interaction, or as Augé writes: "The space of non-place creates neither singular identity nor relations; only solitude and similitude" (1995: 103). It is a space frequented by people, and large groups of people, but deprived of interaction between them, or even their respective individualities. These places are filled with solitude, as if they were empty rooms, with four uniform walls. They house nothing of interest, and despite their intended appeal to potential shoppers or consumers, they are deprived of uniqueness. Examples of these places would include highways, stations, airport waiting areas and of course, supermarkets. All these places have in common the fact that people pass through them without the need to interact with one another, and have only textual signs to guide them (Ibid.: 94, 96).

If we wanted to compare a non-place to another concept, to attain a better understanding of it, Augé would suggest the "utopia." If a utopia is an ideal place in terms of human relations, a non-place is deprived of any "organic society" (Ibid.: 112). The latter does however exist, unlike the former. In that sense, a non-place is also similar to a dystopia, but it cannot be overtly regarded as such since even chaos and terror require people to acknowledge them and more importantly, to react to them, and inside them. A non-place is characterized by the lack of all human relations, good and bad.

If they are not innately designated as "bad," non-places can be good, which is, as Augé defines it, their paradox (Ibid.: 106). The similitude present in them can act as a cohesive device, providing a stranger in the non-place surroundings with an opportunity to recognize a place he might feel attached to, since he has encountered such sterile places in his place if origin. The best example would be the way airport cabin crews lead their lives, constantly changing time zones and more importantly - hotels, which after a while all appear the same to them, which is in the light of Augé's theory not far from the truth. Constant estrangement paradoxically gives rise to a sense of belonging and familiarity.

Finally, we must understand that non-places are not rigid categories. The creation of places is perpetual and it occurs every time "humans invest meaning in a portion of space and then become attached to it in some way" (Creswell 2004: 10). Non-places can thus recuperate their meaningfulness and change back into places. Augé provides us with the example of a countryside home (1995: 107), while writing about the reverse process of places becoming non-places. A village once brimming with life can become desolate and

\footnotetext{
${ }^{2}$ Creswell underscores that "location is not a necessary or sufficient condition of place" (2004: 22).
} 
due to immigration to the urban areas degrade into a mere toponym on the map. ${ }^{3}$ The process is reversible: a city dweller might wish to buy a house in such a village, bringing it back on the mental map of the populace. In this paper, however, we deal with a more urban representation of a non-place: a place for shopping called a supermarket.

\section{SUPERMARKET AS A NON-PLACE}

Augé provides us with the following description of the supermarket as a non-place: "the habitué of supermarkets ... communicates wordlessly, through gestures, with an abstract, unmediated commerce; a world thus surrendered to solitary individuality, to the fleeting, the temporary and ephemeral" (Ibid.: 78). The most important trait of the supermarket when compared to the local grocery store is the abundance of words with which the customer is confronted with, but which all lack a communicative function. Almost all of the inscriptions, from the working hours at the door, to the "thank you" note on the fiscal slip, have an ephemeral meaning which is relevant only for a few seconds. After all, it is the present moment that reigns in a non-place, since everything is measured in the units of time (Ibid.: 104).

The shoppers must navigate a myriad of signs which are thrown at them. Even the employees are not talkative since they mile around preoccupied with the merchandise, rather than the customers. Stocking shelves and checking prices seems to be their main preoccupation, or as Baudrillard formulates it: "there are employees who are occupied solely in remaking the front of the stage, the surface display, where a previous deletion by a consumer might have left some kind of a hole" (1995: 52). Most cashiers keep the communication to a minimum and are seldom ready to engage in conversation about topics other the ones related to the immediate purchase. The shopper is "condemned" to communicate with sounds and signs on his way through the supermarket, or as Augé writes: "the space shoppers occupy is invaded by text" (1995: 99).

The word "way" is essential here since we move through the store as on a conveyor belt: we enter the store through a narrow passage, mill through the shelves and exit through narrow points where we have to pay. Much like the ontological structure of a highway, the whole shopping experience is centered on motion which the supermarket cannot do without. One is constantly in need of relocation, and the notion of rest is vanquished from the whole of the supermarket. The eternal motion is not only spatial, but temporal as well: more and more supermarkets are open 24/7, never closing their doors, not even when the majority of their potential shoppers are asleep. Allen Ginsberg evokes this image in his 1955 poem "A Supermarket in California" singing of "whole families shopping at night," criticizing the American society of his time in the same manner DeLillo did thirty years later. The perpetual possibility of shopping facilitates the "traffic conditions of space" (Augé 1995: 96), and it seems that the shoppers propel the markets to stay open all night.

The "solitude and similitude" generated in the supermarket are more than apparent. Shoppers are basically left on their own as they endeavor to navigate a forest of generic signs, systematically deprived of the opportunity to socially interact with a member of the staff who is always absent or when present, not talkative. People seemingly move on their own through the uniformly stacked shelves of the supermarket, but they actually traverse well-planned

\footnotetext{
${ }^{3}$ Maps are a step further in the process of depriving a space of meaning, taking an entire spatial facet away, since they are two-dimensional (Relph 1976: 22).
} 
routes ${ }^{4}$ between the fixed entry and exit points. If one is on the constant move, keeping track of ephemeral data, the possibility for a social interaction decreases significantly. Thus, supermarkets can be considered non-places since social interaction, the basic ingredient of any anthropological space, is kept to a minimum.

There are of course, researchers who oppose Augé's standpoint which we promulgate in this paper, but their arguments are weak. Goidanich and Rial claim that there is no loneliness in the supermarket (2012: 152), based on the fact that people interact in food courts where they are able to sit and talk (Ibid.: 149) and that shoppers use their mobile phones on the premises of the supermarket (Ibid.: 152). The former claim is false since not all shopping centers have food courts and they are certainly never located inside a supermarket. ${ }^{5}$ The later claim is false to that extent that it actually supports Augé's theory: using a cell phone whilst surrounded with other people is an example of ambient intimacy and strengthens the solitude associated with the non-place.

\section{THE SYMBOL OF THE SUPERMARKET IN WHITE NOISE}

Don DeLillo's 1985 novel abounds in symbols, but the symbol of death is the one most often promoted by the critics (LeClair 2002: 11; Weinstein 2002: 142; Conroy 2002: 161; Frow 2002: 44-45). The novel's title is considered a metaphor for death. This consumerist setting was not randomly chosen by DeLillo since it is not a common setting for novel. Weinstein asks the right rhetorical question: "how many novelists take us to supermarkets" (2002: 129)? The supermarket is perfectly suited for the metaphor of death since it "too has 'location', but that location lies below or above the appropriated social space" (Lefebvre 1991: 35). In other words, the ontological concept of death cannot occupy a place in the conventional manner, but it rather lingers in spaces which humans cannot define. The non-place is the first step in the process of the deconstruction of space and death can inhabit it as such. DeLillo's whole novel is about decaying, and the supermarket is the perfect place for this covert dying out.

The author wishes to inform us early on that the social entropy he wishes to portray incorporates consumerism, the temple of which is the supermarket, or as LeClair formulates is: "DeLillo's early vision of America [is that of] a consumer nation symbolized by the supermarket (2002: 12). "When times are bad, people feel compelled to overeat" (DeLillo 2009: 14) and they buy food at the local supermarket in Blacksmith, which is neatly placed in the village's center (LeClair 2002: 12). It is a "virtual omphalos" (Conroy 2002: 166), where many of the novel's scenes take place, including the very last scene and the subsequent conclusion spoken in supermarket terms. Baudrillard writes that "the traditional market was in the heart of a city, a place where the city and the country came to rub elbows" (1995: 53), meaning that this new kind of market wishes to supplant the older, the more "anthropological" site for shopping.

The first time we are introduced to this building, we are faced with an image of "similitude and solitude" in the form of the "elderly" who are selecting shopping carts from the line outside the supermarket (DeLillo 2009: 14). Pensioners are usually regarded

\footnotetext{
${ }^{4}$ Most supermarkets keep the snack shelf adjacent to the shelf with beer. This highly suggestive trick by the trade companies actually significantly decrease the number of possible routes a shopper can take in the supermarket.

${ }^{5}$ The management of supermarkets frequently feel the need to post a sign prohibiting the consummation of food and beverage on the premises.
} 
as being lonely, since old age is associated with a growing sense of loneliness. They approach shopping carts which have been lined neatly outside the supermarket: tens of identical baskets with wheels suggest that the inside of the building is a shrine of linearity. These forms can be regarded as "arrows [that] point you toward these large triage centers that are the hypermarkets, toward this hyperspace of the commodity where in many regards a whole new sociality is elaborated" (Baudrillard 1995: 52). All the signs are highly suggestive, as the steel cages usually point toward the entrance of the supermarket.

These empty carts are highly suggestive since they yearn to be filled. The most suitable character for shopping in the novel is Murray Jay Siskind, whom the protagonist and his wife meet in the supermarket. His cart is full of generic food and drinks and non-brand items in white packages ${ }^{6}$ unimaginatively labeled as CANNED PEACHES or IRREGULAR PEANUTS (DeLillo 2009: 18). Moreover, Siskind rejoices that the product he bought are so utterly plane, and for the first couple of minutes talks about the artistic value of such packaging, taking out the items from Jack and Babette's cart and admiring them. His comic ability to admire a bag of peanuts is an elegy for the shopper: "I've bought these peanuts before. They're round, cubical, pockmarked, seamed. Broken peanuts. A lot of dust at the bottom of the jar. But they taste good. Most of all I like the packages themselves" (Ibid.: 19). The writer's criticism of a consumer society could not be more obvious: the packaging comes before taste, and here is not even a mention of quality, nor healthiness. As Frow rightly notices, "the supermarket is the privileged place for a phenomenology of surfaces" (2002: 47).

In the background we can hear a laconic dialogue between the checkout girl and another worker, typical of a non-place:

- "Leon, parsley.".

- "Seventy-nine" (DeLillo 2009: 19).

These hollow words only emphasize Siskind's pointless tirade about philosophy. His erudite speech is quite literally out of place. A place where books, as symbols of knowledge, are scattered across the entrance. The paperbacks could possibly obtain a better location since the members of the academia have exchanged their campus offices with the supermarket. As Jack Gladney confers to the reader: "This was the fourth or fifth time I'd seen him [Murray Jay Siskind] in the supermarket, which was roughly the number of times I'd seen him on campus." (Ibid.: 35). Those who are supposed to be learned, nowadays gain their knowledge from the tabloids (Saltzman 2002: 202). Jack and Babette naively believe yellow journalism: "Some people actually do it, according to a headline I saw at the supermarket" (DeLillo 2009: 270).

The supermarket is so gaudy, orderly and noisy that even the author notices on several occasions these traits that make it a non-place:

The bins were arranged diagonally and backed by mirrors that people accidentally punched when reaching for fruit in the upper rows. A voice on the loudspeaker said: "Kleenex Softique, your truck's blocking the entrance." Apples and lemons tumbled in twos and threes to the floor when someone took a fruit from certain places in the stacked array. There were six kinds of apples, there were exotic melons in several pastels. Everything seemed to be in season, sprayed, burnished, bright. People tore filmy bags off racks and tried to figure out which end opened. I realized the place was awash in noise. The toneless systems, the jangle and skid of carts, the loudspeaker and coffee-making machines, the

\footnotetext{
${ }^{6}$ Many retailers have private brand whose diverse products share the same name and the same plain packaging. Some of the private brands in the Serbian market in 2015 include: Dobro ("Good"), K Plus, Top Budget, Baš $B a \check{s}$ (,Really Really [Good]“), Premia etc.
} 
cries of children. And over it all, or under it all, a dull and unlocatable roar, as of some form of swarming life just outside the range of human apprehension. (Ibid.: 36, italics added)

I was suddenly aware of the dense environmental texture. The automatic doors opened and closed, breathing abruptly. Colors and odors seemed sharper. The sound of gliding feet emerged from a dozen other noises, from the sublittoral drone of maintenance systems, from the rustle of newsprint as shoppers scanned their horoscopes in the tabloids up front, from the whispers of elderly women with talcumed faces, from the steady rattle of cars going over a loose manhole cover just outside the entrance. Gliding feet. I heard them clearly, a sad numb shuffle in every aisle. (Ibid.: 160-161, italics added)

The "noise" in first paragraph foreshadows the disaster at the end of the novel which is evident in the second paragraph. The given excerpts centred around noises provide us with a significant factor in any non-place: meaningless sounds. The overall noise the protagonist takes notice of is nothing less than a failed attempt of communication. Instead of asking an employee, the customers must touch the products to inspect them, and there is a dull voice from the loudspeaker saying words completely irrelevant to the shoppers. ${ }^{7}$ Jack mistakes this noise for a sign of "swarming life," but it is actually a waste sound of humanity. It symbols not only the death looming over the novel's characters, but the death of an anthropological place, which the supermarket is not.

Precisely because of this void, the novel's most ardent shopper is in need of a grand ontological role for something as plain as a store. For Siskind, the supermarket symbolizes a transience, it is "a gateway or pathway" to a more spiritual plain (Ibid.: 37). Surprisingly enough, he is right to think so, since a non-place is a place of motion, and if we recall, highway is one of the examples of a non-place Augé lists. While discussing Augé's term, Creswell defines it as "a place for travellers" (2004: 46), denoting the transient aspect of a non-place. Baudrillard believes that in this sense, the highway and the supermarket are intrinsically connected: "The hypermarket cannot be separated from the highways that surround and feed it, from the parking lots blanketed in automobiles, from the computer terminal - further still, in concentric circles - from the whole town as a total functional screen of activities" (1995: 52). This description is brimming with life or more precisely: motion. LeClair also refers to Siskind's standpoint of the supermarket brimming with movement in the form of communication and messages (2002: 26). It is about moving on, but in a less spiritual way Siskind would like it to be; it is rather "moving on" in a queue for the cash register. The author even uses the same word for moving inside the supermarket as Augé: "traffic of carts and gliding bodies" (DeLillo 2009: 39). Siskind is correct, however, about the temporal dimension of the supermarket. It is "timeless" due to its open hours and the definition he provides us with coincides with the effect a non-place produces: "Here we don't die, we shop. But the difference is less marked than you think" (Ibid.: 38). The motif of death is deprived of a metaphor as it is clearly stated that shopping is dying.

As we have stated earlier, this death is partly because of the interruption of communication. Jack complains that at the cash register, through which every shopper must pass, not every shopper speaks English. Furthermore, he hears foreign languages he cannot

\footnotetext{
${ }^{7}$ In another DeLillo novel, Underworld, there is a reference to monitors installed "to keep shoppers occupied at the checkout" (1998: 94), which adds the dimension of the image to the communication inside the supermarket. Writing on the topic of the communication process in the supermarket, Baudrillard also makes references to a "total screen" and an "uninterrupted display" (1995: 52).
} 
distinguish, let alone understand throughout the supermarket (Ibid.: 40), further adding to the cacophony of people who fail to successfully establish communication.

One of the main arguments of those who do not perceive the supermarket as a non-place is the existence of human communication inside the supermarket. In DeLillo's novel, other than Siskind's vapid soliloquies, there is little intimate interaction. Jack Gladney, the spouse of Babette Gladney, refers to touching his wife as "rubbing against" her (Ibid.), as if he rubbed against the edge of an object. The two have a tumultuous relationship as she cheats on him, and Siskind courts her incessantly, mainly on the premises of the supermarket. Furthermore, the checkout women remind Jack of the prostitutes he later encounters in Iron City where he travels to confront his wife's lover (Ibid.: 143). The man in question, Willie Mink, is a scientist turned a drug dealer, and reminds Jack of the boys who bag the "merchandise" at the end of the checkout counter (Ibid.: 263). He derived the comparison in question because they are both plain looking, doltish even. Supermarket is a place where Jack cannot express emotions he might or might not have toward his wife, where the female cashiers are faceless to him, ${ }^{8}$ deprived of their sex and plain (white) as the products they sell, and where the workers are even-tempered as seasoned criminals.

If we were to go back to the elderly people mentioned at the beginning of the novel, they are the most frequent shoppers. Based on what DeLillo writes, they are the perfect visitors (or commuters) of non-places as well: solitary, disoriented, torpid, and senile, they wander aimlessly through the aisles (Ibid.: 159). When they arrive in the store in the morning, the supermarket can retake its pedestal as a non-place in super modernity. DeLillo sums up its present-oriented nature and the importance it holds in a consumer society: "Everything was fine, would continue to be fine, would eventually get even better as long as the supermarket did not slip" (Ibid.: 162).

Unfortunately for the protagonists, the supermarket does "slip" at the end of the novel. The elderly are the first to take notice that the shelves have been rearranged. The panic and the dismay between the aisles are assuaged only by the fact that "only the generic food is where it was, white packages plainly labeled" (Ibid.: 309). The world of the novel has been hollow to such an extent that the most artificial part of the supermarket has survived the disaster and now serves as a guidepost to the disillusioned people. The "place" where human interaction has been kept to a minimum must now serve a symbolical role, as the one prophesized by Siskind throughout the novel. The apparatus of estrangement assumes a far greater role: "the terminals are equipped with holographic scanners, which decode the binary secret of every item, infallibly. This is the language of waves and radiation, or how the dead speak to the living" (Ibid.: 310). The inherently meaningless place is made to harbour meaning; a nonplace is turned into a place, which is a true ending to a world ruled by noise. In other words, the supermarket "stands as a symbol of a physical magnitude that can help master death" (LeClair 2002: 12). The ontological change of a non-place is an unmistakeable sign of the ensuing death, symbolized in the white noise, which ran through the novel.

\footnotetext{
${ }^{8}$ In DeLillo's 2007 novel, Falling Man, one of the protagonists cannot remember the name of the woman at the cash register, presuming that it is either "Meg" or "Peg" (110).
} 


\section{CONCLUSION (PRESENT-DAY SUPERMARKETS)}

If we have in mind what a non-place is, in which way a supermarket is an epitome of it, and how DeLillo had presented us with his vision of the supermarket, it is almost unnecessary to conclude that in present-day Serbia we are living the non-place supermarket. This was not true in the novel's publication years, 1985, since the market in Yugoslavia was not free as the one in the United States of America. In the recent decade, consumerism has turned the grocery stores into supermarkets which resemble the one described in White Noise. They are all essentially non-places and are showing all traits of them. The self-service checkout cash register from the introductory anecdote was considered as an innovation in doing business, a step forward in retailing. The concept of progress is today unmistakably related to the process of estrangement in Serbian society. One extreme case of this change was described in DeLillo's novel and can serve as a guideline to the events taking place in supermarkets today. Elderly shoppers are the ones who approach shopping most proactively: they check each product several times, participate in numerous promotional campaigns and are ready to protect the integrity of the queue at the cash register. ${ }^{9}$ The shelves are stocked with private brands which advertise the price rather than the quality. There is even the noise, although less ominous than in the novel, but it still tampers with human communication. Conversations are shortened because the main goal of frequenting a supermarket is the act of buying, which is paradoxically closely associated with the act of "saving money." Longer conversations are scarce since communication takes place mostly through signs. However, unlike the society in the novel, there are certain signs that the supermarket, although it is a non-place, can act as an anthropological place to a certain extent. Missing from the anecdote at the beginning of the paper is the retort of the worker: she had actually said "goodbye" after she recuperated from the initial conversational shock. This goes to show that interactions do occur in the supermarket, as Goidanich and Rial suggest. Although the relationships established there are not sufficient to promote it to a proper place in the ontological sense, they do represent stages in the long process of conversion of the non-place, as we have pointed out in the final chapter of Sect. 1. Although they are uniform, non-places do exist inside a given society. DeLillo utilized this fact to make the Blacksmith supermarket extra cacophonic, perfectly fitting it into a novel whose plot revolves around death preceded by entropy. Taking this into consideration, it is quite possible that the non-place supermarket present in Serbian society has not yet taken its full shape, and could, in the near future, assume a less "dystopian" form than that of its literary counterpart from White Noise.

\section{REFERENCES}

Augé, M., (1995), Introduction to an Anthropology of Supermodernity, Trans. J. Howe, London; New York, Verso.

Baudrillard, J., (1995), Simulacra and Simulation, Trans. S. F. Glaser, Ann Harbor, University of Michigan Press.

Conroy, M., (2002), "From Tombstone to Tabloid: Authority Figured in White Noise." In: Bloom, H. (ed.) Bloom's Modern Critical Interpretations: Don DeLillo's White Noise, Philadelphia, Chelsea House Publishers: pp. 153-168

Cresswell, T., (2004), Place: A Short Introduction, Oxford, Blackwell Publishing.

DeLillo, D., (1998), Underworld, New York, Scribner.

${ }^{9}$ N.B. The author does not wish to insult elderly people; the observation is based on his numerous accounts of such behavior witnessed in the supermarket queue. 
DeLillo, D., (2007), Falling Man: A Novel, New York, Scribner.

DeLillo, D., (2009), White Noise, London, Penguin Books.

Frow, J., (2002), “The Last Things Before the Last: Notes on White Noise," In: Bloom, H. (ed.) Bloom's Modern Critical Interpretations: Don DeLillo's White Noise, Philadelphia, Chelsea House Publishers: pp. 35-49.

Ginsberg, A., (1955), “A Supermarket in California.”, Academy of American Poets, https://www.poets.org/ poetsorg/poem/supermarket-california. Accessed 9 Oct. 2015

Goidanich, M. E., and Carmen Rial, (2012), "A Place Called Supermarket," International Review of Social Research 2/1: pp. 143-156.

LeClair, T., (2002), "Closing the Loop: White Noise. In: Bloom H. (ed.) Bloom's Modern Critical Interpretations: Don DeLillo's White Noise," Philadelphia, Chelsea House Publishers: pp. 5-33.

Lefebvre, H., (1991), The Production of Space, Trans. Donald Nicholson-Smith, Oxford; Cambridge, Blackwell

Relph, E., (1976), Place and Placenessness, London, Pion Limited.

Saltzman, A. M., (2002), "The Figure in the Static: White Noise," In: Bloom H. (ed.) Bloom's Modern Critical Interpretations: Don DeLillo's White Noise, Philadelphia, Chelsea House Publishers: pp. 195-212.

Weinstein, A., (2002), “Don DeLillo: Rendering the Words of the Tribe.” In: Bloom H. (ed.) Bloom 's Modern Critical Interpretations: Don DeLillo's White Noise, Philadelphia, Chelsea House Publishers: pp. 117-152.

\section{POSTOJANOST SUPERMARKETA KAO NEMESTA U ROMANU BELA BUKA DONA DELILA}

U radu se ispituje supermarket kao mesto radnje i kao nemesto u romanu Dona Delila Bela buka, objavljenom 1985. godine, kao i postojanost ove tematike u savremenoj kulturi. Kritičari su se mahom bavili potrošačkim $i$ religijskim ulogama supermarketa u romanu, pritom zanemarujući njegove prostorne implikacije. Koncept supermarketa kao mesta prisutan je u filozofskoj misli francuskog antropologa Marka Ožea, koji je poslednje decenije dvadesetog veka skovao prigodan termin „nemesto“. Cilj ovoga rada jeste da nesumnjivo potvrdi da Delilova zamisao supermarketa koju je izložio u Beloj buci, u potpunosti se poklapa sa Ožeovim konceptom nemesta. U druga nemesta spadaju: hotelska soba, auto-put ili aerodrom. Takođe, postoji razlika između termina , prostora“ “ $i$ „mesta " koja je suštastvena za nastanak nemesta, poput supermarketa. Ova zona za kupovinu je označena prelaznošću $i$ oformljena je sa jasnom namerom, ali je istovremeno $i$ mesto sa kojim se može poistovetiti, kao što to čine brojni Delilovi junaci u romanu. Postojanost supermarketa kao nemesta se može pronaći $i$ u savremenom kulturološkom kontekstu. Današnja simbolika supermarketa jeste istovetna onoj o kojoj su pisali Delilo i Ože; jedan autor sa književnog, a drugi sa teorijskog stanovišta.

Ključne reči: Supermarket, Bela buka, nemesto, Don Delilo, prostor 